УДК 94:373.](477.5)'’1805/1860"

DOI https://doi.org/10.31470/2518-7600-2021-12-89-104
THE ROLE OF PUBLIC INITIATIVE IN EXPANDING THE NETWORK OF PRIMARY SCHOOLS IN LEFT- BANK UKRAINE IN 1805-1860

\title{
РОЛЬ ГРОМАДСЬКОЇ ІНІЦАТИВИ У РОЗШИРЕННІ МЕРЕЖІ ПОЧАТКОВИХ НАВЧАЛЬНИХ ЗАКЛАДІВ НА ЛІВОБЕРЕЖНІЙ УКРАЇНІ В 1805-1860 РР.
}

\section{РОЛЬ ОБЩЕСТВЕННОЙ ИНИЦИАТИВЫ В РАСШИРЕНИИ СЕТИ НАЧАЛЬНЫХ УЧЕБНЫХ ЗАВЕДЕНИЙ НА ЛЕВОБЕРЕЖНОЙ УКРАИНЕ В 1805-1860 ГГ.}

Інна Левченко,

доктор історичних наук,

професор кафедри теорії та методики професійної

підготовки

inna.lewchenko2000@ukr.net

https://orcid.org/0000-0001-

9652-8755

ID: D-1140-2019

Університет Григорія

Сковороди в Переяславі,

м. Переяслав,

вул. Сухомлинського, 30,

Київська обл., Украӥна, 08401
Inna Levchenko,

Doctor in Historical Sciences, Associate Professor of the Department of Theory and Methods of Vocational training inna.lewchenko2000@ukr.net https://orcid.org/0000-00019652-8755

ID:D-1140-2019

Hryhoriy Skovoroda University in Pereyaslav, Pereyaslav, 30, Sukhomlynskoho Str., Kyiv region, Ukraine, 08401

\section{ABSTRACT}

The article examines the problem of formation and functioning of primary schools in the Left Bank of Ukraine in 18051860. The role of the Ministry of Education, which retained control 
functions, and the maintenance of primary schools was transferred to the public.

The position of the conservative part of society, which did not support educational initiatives, and the position of the progressive part of the public, which took the lion's share of funding for the opening, operation and development of county and parish schools in Left Bank Ukraine in the study period.

The main condition for the existence of educational institutions, which consisted in their material support, is revealed. The author mentions the names of patrons who actively influenced the development of the educational process, donated significant funds, books, school supplies, furniture, medicines, housing, etc. to the benefit of schools.

The role of national minorities in the formation and functioning of primary schools in the Left Bank of Ukraine in the period under study is mentioned. In particular, the initiative of the Nizhyn Greeks, who were concerned about the educational problems of their compatriots, is covered.

The article highlights the role of honorary guardians and supervisors of county schools, who often became their permanent patrons. Concerned with economic problems, they tried to improve the learning conditions of their wards. The facts that testify to their selfless charitable work, which consisted of constant donations, are indicated.

Bilateral financing of primary schools is considered, which consisted of providing financial assistance from honorary guardians (supervisors) of schools, as well as individuals.

Keywords: primary schools, county schools, honorary guardian, donations, patrons, public initiative.

Постановка проблеми. Освіта є основою культурного i соціально-економічного розвитку суспільства. Без освіти неможливе відтворення творчого потенціалу народу, національного відродження, становлення державності на принципах демократизації суспільних відносин. 
Без широкої і глибоких освіти народних мас неможливе існування національної свідомості суспільства, що було особливо актуальним для українського народу в період перебування України у складі Російської імперії, політика якої спрямовувалась на русифікацію неруських народів, позбавлення їх історичного коріння та національної самобутності.

Така політка царизму знаходила підтримку і виправдання його ідеології, у тому числі й науковців, які всіляко вихваляли iii спрямованість й результативність. Протилежну позицію в оцінці освітньої діяльності царського уряду займала радянська історіографія. Виходячи 3 класових позицій оцінки всіх процесів, вона, у своїй більшості, зображувала царизм ворогом народу в соціально-економічних процесах i одночасно замовчувала роль представників заможних верств населення у культурно-освітній діяльності. Такі підходи до визначення ролі різних політичних сил у галузі народної освіти були однобічними і суб'єктивними. Звідси випливає і важливість максимально об'єктивного, без ідеологічних штампів і зашореності, дослідження ролі народної ініціативи в розвитку середньої освіти, зокрема, професійного спрямування, на Лівобережній Україні в 1805-1860 pp.

Аналіз досліджень і публікацій. Перші дослідження, в яких розглядалось становище початкової освіти в XIX ст., 3'явилися в роки досліджуваного нами періоду, але всі вони мали узагальнюючий характер. Питання милосердя та благодійності як високих етичних норм висвітлюються у праці А. Андріяшева (Андрияшев, 1865). Причини зникнення парафіяльних училищ висвітлюються у праці І. Павловського (Павловский, 1914). В незначній мірі автор досліджує питання меценатства в освітній сфері, питання милосердя та гуманізму.

Серед сучасних дослідників слід відмітити напрацювання В. Борисенка (Борисенко, 1980), Г. Самойленка (Самойленко, 1996), Ф. Ступака (Ступак, 1997), Б. Ступарика (Ступарик, 1994), О. Крижановської (Крижановська, 1997), де 
висвітлюється боротьба демократичних сил за народну освіту на Україні в XIX - на початку XX ст. Однак цілісного дослідження, в якому б розглядалась громадська ініціатива у розширенні мережі початкових навчальних закладів на Лівобережній Україні у 1805-1860 рр. немає.

Метою статті є дослідження громадської ініціативи в становленні початкових навчальних закладів на Лівобережній Україні в 1805-1860 pр.

Виклад основного матеріалу. Стан середньої освіти в досліджуваний період перебував на низькому рівні. Царизм боявся надати широким народним масам середню освіту, але не міг й виступати відкрито проти неї, оскільки розвиток господарства і суспільного життя вимагав освічених кадрів. Тому царське самодержавство пішло по шляху запровадження класичного напряму освітнього процесу, який би задовольняв ці потреби й одночасно гальмував розвиток матеріалістичного світогляду в підростаючого покоління.

Незважаючи на те що, правлячі кола країни в переважній більшості побоювалися поширення знань серед широких верств населення, вони змушені були вживати певних заходів 3 розвитку мережі навчальних закладів різного рівня. Уряд надав можливість одержати не тільки середню, а й вищу освіту представникам недворянських (Різночинських) верств населення.

До того ж російському уряду потрібні були державні чиновники, підготовлені на європейському рівні. Професіоналів потребували промисловість і торгівля (Прокопенко, 2008: 187). Водночас правлячі кола Росії чітко усвідомлювали ту загрозу громадським засадам, які виходили від поширення освіти серед широких мас.

У 1802 р відповідно до Маніфестом Олександра I створюється Міністерство народної освіти, якому підлягали майже всі вищі, середні і нижчі навчальні заклади, Академія наук, друкарні, культурні установи і т.д. 
Основні принципи державної системи народної освіти були сформульовані «Статут університетів Російської імперії» i «Статут навчальних закладів, підвідомчих університетам» від 1804 г. (Прокопенко, 2008: 188). Філософською основою російської системи освіти стали твори французьких просвітителів.

Але передові ідеї педагогіки наклалися на грунт петровської і катеринської епох, які утворилися внаслідок системи загальної освіти, що складалася з чотирьох ланок. Нижньою ланкою системи освіти стали парафіяльні училища.

Царизм намагався перекласти витрати на освіту народу на його плечі, фактично повністю самоусунувшись від них. Тому створення парафіяльних училищ відбувалось досить повільно і малопомітно. Князь О. Б. Куракін прагнув залучити дворянство до їх влаштування і звернувся 3 відповідною пропозицією до всіх повітових маршалів Полтавської та Чернігівської губерній. Розрахунок генерал-губернатора на те, що в дворянстві, як культурному класі суспільства,він зустріне співчуття, не справдився. Це був час кріпосного права, коли про освіту кріпаків не тільки не думали, але вважали іiі зайвою і непотрібною. Багато дворян навіть не відповіли князеві, інші дали знати про отримання його пропозиції і тільки деякі висловилися 3 цього питання. Лише полковник М. Козицький, зокрема, обіцяв для цієї благодійної справи пожертвувати 200 крб. асигнаціями (Павловский, 1906: 121). Більше відгуків на пропозицію князя Куракіна не надійшло.

I. Ф. Павловський у своїй праці «Полтавцы, иерархи, государственные и общественные деятели и благотворители» (1914), згадує лише єдиний випадок заснування початкової школи поміщиками Полтавської губернії в епоху кріпосного права. У селі Чепуровці Пирятинського повіту Полтавської губернії вона була відкрита поміщицею Наталією Чепою (точний рік не вказано). У перший рік існування у ній навчалося 23 учня. Засновниця закладу подала клопотання Полтавському губернатору про дозвіл побудувати нове 
приміщення для школи. За проханням меценатки, їі чоловік Адріан Чепа був призначений наглядачем навчального закладу. Він зобов'язався утримувати 50 учнів з числа бідних селян, забезпечувати їх книгами та іншими посібниками, а тих що будуть показувати гарні успіхи у навчанні, нагороджувати. Вчителі, які працювали у цій школі, теж не залишалися без уваги. Добросовісні «носії знань» за свою працю отримували землю і певну кількість грошей (Самойленко, 1996: 79).

Закінчивши парафіяльне училище, діти мали право навчатися у повітовому училищі, а потім вступити до гімназії. Розпорядження міністра народної освіти графа Розумовського від 18 вересня 1813 р. мало неабиякі наслідки для дітей кріпаків, адже згідно нього, їм заборонялося вступати до гімназії.

Але, не дивлячись на суворі розпорядження, які позбавляли більшість дітей отримати середню та вищу освіту, вони були раді можливості навчатися і в початковій школі.

Розуміючи важливість відкриття початкових навчальних закладів, громадськість Лівобережної України почали більш активніше впливати на цю ситуацію. Так, дворяни м. Кролевця Чернігівської губернії пожертвували необхідну суму грошей, придбавши за них будинок. Найбільш активнішим у цій благодійній справі був поміщик Кролевецького повіту Н. Бардаков. Згодом його обрали почесним опікуном закладу (Андрияшев, 1865: 43).

У першій половині XIX ст.. нижча ланка освіти перебувала у скрутному матеріальному становищі. Міністерство освіти абсолютно не опікувалось фінансовими витратами парафіяльних та повітових училищ. Учні не мали можливості навчатися за підручниками державного зразку, приладдя використовувалися в дуже рідких випадках. Саме завдяки громадськості початкові навчальні заклади почали отримувати відчутну фінансову допомогу, яка надходила від меценатів у вигляді пожертвувань. 
Так, генеральний суддя Петро Ілларіонович Селецький у 1821 р. зробив пожертвування Пирятинському повітовому училищу Полтавської губернії у розмірі 500 крб. асигнаціями, що стало відчутною матеріальною допомогою. Але дана акція не стала одноразовою. 31822 р. меценат щороку жертвував близько 101 крб. на різні потреби (Ступарик, 1994: 56-67).

Почесні наглядачі училищ виконували, зазвичай, всі господарські функції, але нерідко, саме вони ставали меценатами своїх навчальних закладів. Так, у 1814 р. на користь Лубенського повітового училища надійшла сума у розмірі 200 крб. асигнаціями від почесного члена П. О. Лисенка (Астряб, 1914: 138). Кошти призначалися для ремонтування приміщення школи та лагодження меблів.

Почесний наглядач Миргородського повітового училища Полтавської губернії М. Корсун у 1819 р. пожертвував на користь закладу 35 крб. асигнаціями для першочергових потреб учнів (Борисенко, 1980: 80).

У кожному училищі була книга, призначена для записів пожертвувань, які надходили від громадськості. Пирятинське повітове училище вирішило надати можливість вести записи самим благодійникам. У книзі зазначалося: «Для запису пожертвувань від приватних осіб на користь Пирятинського повітового училища принесені, щоб назавжди зберегти в пам'яті і для нащадків почесні імена благодійників, які допомагають державі патріотичними пожертвуваннями для загальної користі». Після слів директора училища М. Огнєва були зазначені пожертвування від О. К. Закревського - 50 крб, почесного наглядача О. Вакуловича - 100, надвірного радника С. Забєли - 50, поручика В. Тарновського - 25, обер-аудитора I. Трояновського - 50, колезького радника Щербака - 50, колезького секретаря П. Комаровського - 5, надвірного радника Грабовського - 10, штабс-капітана Я. Савицького - 25, Катерини Савицької - сріблом 1 крб., поручиком Д. Лачинським - 10, губернським секретарем М. Горбаневським - 15, капітаном С Гамалією - 10, князем 
О. Жеваковим - 50, колезьким асесором М. Григоровичем -4 , місцевим головою з громадою - 100, титулярним радником С. Мокрицьким, прапорщиком - П. Судовщиком - 15, титулярним радником Ф. Юзефовичем - 5, колезьким секретарем М. Корсуном - 5, губернським секретарем О. Ненадським - 5, поручиком Я. Свічкою - 25, колезьким регістратором I. Зайковським - 10 крб. асигнаціями і т. д. (Ступак , 1997: 17).

Розвитку початкової освіти на Лівобережній Україні сприяли також місцеві греки. Значна кількість населення грецького походження проживала в місті Ніжині. Вони, в свою чергу, розуміючи необхідність освітнього процесу для дітей, у 1811 р. створили власний капітал для своїх співвітчизників, завдяки якому у 1817 р. згідно наказу імператора Олександра I було відкрито грецьке училище. Ініціатором цього задуму був Стефан Кирилович Буба, грек за національністю та меценатом від серця. Благородна мета С. Буби була підтримана іншими греками. Протягом шести років була зібрана сума у розмірі 86000 крб. асигнаціями та була передана Московській казні. Головним опікуном навчального закладу був грецький Ніжинський магістрат, який повинен був 3 відсотків пожертвуваної суми утримувати навчальний заклад (Самойленко, 1996: 17).

Меценатську діяльність греків схвалив імператор Олександр I, нагородивши головного засновника училища С. К. Бубу орденом св. Володимира 4 ступеня.

Важливе значення для розгортання освітнього руху на Лівобережній Україні в зазначений період мала діяльність декабристів. Вони на власні очі бачили негативні наслідки неосвіченості й забитості народу, розуміли неможливість розвитку країни в таких умовах і тому критикували систему

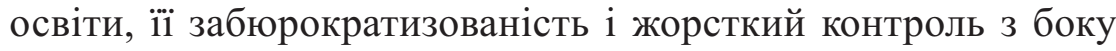
властей.

Активну позицію в освітній сфері відстоювали братидекабристи Муравйові-Апостоли. Вони у своєму маєтку 
Хомутець Миргородського повіту Полтавської губернії, переймаючись освітою серед кріпаків, надавали можливість грамотним мешканцям села користуватися книгами зі своєї бібліотеки. Меценатом в освітній сфері став також борець за державні права України, письменник-просвітитель В. В. Капніст. Обіймаючи державні посади, зокрема, директора народних училищ Полтавської губернії, В. Капніст неодноразово надавав фінансову допомогу закладам освіти, в яких навчалися діти бідних кріпаків. Слід зазначити, що його справу продовжили син Олексій та вихованець М. І. Лорер, які були відомими декабристами. Разом вони поширювали художні та літературні твори, які мали заклики до відстоювання громадянської позиції у всіх сферах соціального життя (Сергієнко, 1980: 59-61).

Частина українського суспільства дотримувалась консервативних поглядів на освіту народу. Вона не бачила і не розуміла тих змін в економіці країни, в духовності людей, які вимагали не лише професійних, але й інтелектуальних знань. Тому освічені консерватори з числа заможних верств населення вважали, що діти бідних батьків не повинні були вчитись, а 3 малих літ працювати для матеріального забезпечення сімей. У кращому випадку вони допускали отримання цими дільми тільки тих елементарних знань, які були їм потрібні у сільському господарстві, ремеслі, повсякденному побуті.

Небайдуже до розвитку початкової освіти поставилось дворянство Кролевецького повіту Чернігівської губернії. Його прогресивні представники підняли питання про щкільні справи на дворянському зібранні і домоглися позитивного по ньому рішення. Активісти-дворяни підготували відповідну громадську позицію і зібрали необхідну суму для влаштування в м. Кролевці повітового училища. Вони в другій чверті XIX ст. купили для нього будинок і забезпечили його всім необхідним для нормальної роботи. Велика заслуга в цій благодійній справі належала вчителю Чернігівської гімназії Бардакову, який добровільно взяв на себе виконання різних організаційних функцій (Андрияшев, 1865: 78). 
Ініціаторами заснування повітового училища в містечку Суражі Чернігівської губернії також були місцеві дворяни. За короткий проміжок часу вони зібрали 634 крб. асигнаціями. Пожертвування надійшли в 1832 р. від колезького асесора К. Г. Гавришева у розмірі 20 крб. асигнаціями, колезького секретаря М.Н. Лшаневича - 15, колезького секретаря Н. М. Цельмана - 6, губернського секретаря I. I. Бондаревського - 10, губернського секретаря А. Мармазинського - 4, канцеляриста Я. Якубовича - 4, старшого лікарського учня I. Ребекіна - 5, колезького секретаря - В. I. Таранова - 25, колезького регістратора А. С. Дублянського - 5, штабс-капітана С. I. Регута - 10, губернського секретаря Ф. М. Бакуревича - 5, штабс-капітана Р. Варзара -5 , канцеляриста С. Тарановського - 5, колезького регістратора Л. Фенчбруєвича - 5, колезького секретаря Д. А. Висоцького - 25, полковника А. В. Енгельгардта - 5, штатської радниці М. Троцької - 25 крб. асигнаціями та від інших (Ступак. 1997: 11-15).

Серед меценатів переважали чиновники губернського i повітового управлінь, що свідчить про відповідний вплив на них керівництва Чернігівської губернії. Серед них був i колезький регістратор Дублянський, який, можливо раніше належав до масонів (Крижановська, 1997: 47).

Дворянство рекомендувало в почесні наглядачі повітового училища губернського секретаря П. Ф. Ширая, який взяв на себе зобов'язання по влаштуванню навчального закладу. На будівництво приміщення він пожертвував 400 колод, 500 шильовок для покрівлі, необхідну кількість цегли для печі. Також за його рахунок був зроблений фундамент будинку, закуплені в необхідній кількості скло та гвіздки. Заробітну платню робітникам, які брали участь в будівництві, меценат зобов'язався платити зі своєї кишені. Необхідна кількість столів, парт, лав були придбані за його рахунок. Із навчальних посібників П. Ширяй пожертвував два глобуси, 5 географічних карт, дошки для арифметичних і географічних 
задач. Його подарунком для училищної зали був портрет імператора. Крім зазначеного благодійник зобов'язався вносити на користь Суразького повітового училища по 200 крб. асигнаціями щороку (Ступак, 1997: 16).

Освітня діяльність громадськості поширювалась і на дітей бідних дворян. Наприкінці 30-х років будинки для них були приєднані до губернських гімназій і перейменовані в пансіони. Ці перетворення спричинили багато незручностей та складностей і серед них, насамперед відсутність спеціальних приміщень, обладнання, коштів. Але завдяки різноманітній підтримці громадськості ці питання поступово вирішувались.

У 1838 р. штаб-ротмістр М. Судієнко пожертвував 30000 крб. асигнаціями на побудову приміщення для пансіону, який мав бути при Чернігівській гімназії. Інші дворяни Чернігівської губернії , в свою чергу, подали пансіону наступну допомогу: почесний опікун Чернігівської гімназії О. Милорадович - 1000 крб. асигнаціями, почесний наглядач В. Лашкевич - 500, полковник В. Ладомирський - 500, новозибківський почесний наглядач М. Лашкевич - 500, колезький асесор I. Юркевич 105 , полковник І. Лизогуб - 100, полковник Д. Милорадович 100, колезький асесор Г. Забєла - 50, М. Селецький - 100, титулярний радник I. Борозна - 100, 3. Тернавський -25 , генерал-майорша О. Ульрих - 25, А. Селецький - 21, граф М. Гудович - 21, Д. Красовський - 21, І. Жданович - 21, I. Богаєвський - 10, П. Рубець - 10, В. Туманський - 10 крб. асигнаціями та багато інших (Ступак, 1997: 12).

Таким чином, у ставленні до державних шкіл для народу серед громадськості Лівобережної України не було одностайності. Частина населення ставилась до них індиферентно, а то й неприязно, інша вбачала в таких школах важливого чинника піднесення культурного рівня народу. Помітний вплив на розвиток освітньої ініціативи на Лівобережній Україні справили прихильники декабристських ідей. Прогресивна частина суспільства, лідерами якої виступали переважно представники патріотичної національної 
знаті, стала ініціатором відкриття більшості державних парафіяльних і повітових училищ.

Провідною силою у створенні мережі приватних початкових навчальних закладів стала прогресивна громадськість в особі поміщиків, чиновників, духовенства i світської інтелігенції. Вони виступили ініціаторами відкриття усіх типів навчальних закладів та несли головний тягар по їх утриманню.

Головною умовою існування початкових навчальних закладів у досліджуваний період було їх матеріальне забезпечення. Воно йшло 3 двох основних джерел пожертвувань почесних опікунів (наглядачів) навчальних закладів і приватних осіб. За рахунок благодійників будувались i ремонтувались шкільні приміщення, поповнювались бібліотеки, купувались меблі, навчальні прилади, надавалась допомога бідним учням.

\section{ДЖЕРЕЛА ТА ЛІТЕРАТУРА}

1. Андрияшев А. Материалы для истории учебных заведений Черниговской дирекции с 1789-1832 г. Киев, 1865. с. 93.

2. Астряб М. І. Столетие Лубенского высшего начального училища (1814-1914). Полтава, 1914. Вып. 4. с. 289.

3. Борисенко В. Й. Боротьба демократичних сил за народну освіту на Україні в 60-90-х роках XIX ст. Київ: «Наукова думка», 1980. с. 154.

4. Крижановська О. О. Історія масонства в Україні: Інформаціно-довідковий словник. Київ, 1997. с. 126.

5. Лавровський Н. О. О древне-русских училищах. Харьков, 1854. с. 198.

6. Павловский И. Ф. К истории Полтавского дворянства 1802-1902 гг. Полтава, 1906. Вып. 3. с. 121.

7. Павловский И. Ф. Полтавцы, иерархи, государственные и общественные деятели и благотворители. Полтава, 1914. c. 279 . 
8. Прокопенко Л. Л. Генеза та розвиток державної освітньої політики в Україні (IX - початок XX ст.): монографія. Донецьк: ДРІДУ НАДУ, 2008. 488 с.

9. Самойленко Г. В., Самойленко О. Г., Самойленко С. Г. Розвиток освіти на науки в Ніжині в XУІІІ - XX ст. Ніжин, 1996. Ч. III. c. 256.

10. Сергієнко Г. Я. Декабристи і Шевченко. Київ: Наукова думка, 1980. с. 187.

11. Ступак. Ф. Я. Діяльність благодійних товариств Києва другої половини XIX-початку XX століття: автореф. дис...к. і. н.: 07.00.01. Київський національний ун-т ім. Т. Г. Шевченка. Київ, 1997. с. 23.

12. Ступарик Б. М. 3 історії становлення гімназійної освіти Український освітній журнал. Київ, 1994. № 1. с. 56-67.

\section{REFERENCES}

1. Andriyashev, A. (1865). Materialyi dlya istorii uchebnyih zavedeniy Chernigovskoy direktsii s 1789-1832 g. [Materials for the history of educational institutions of the Chernihiv directorate from 1789-1832]. Kyiv, 93 [in Russian].

2. Astryab, M. (1914). Stoletie Lubenskogo vyisshego nachalnogo uchilischa (1814-1914). [Centenary of the Lubensk Higher Primary School (1814-1914).]. Poltava, 289 [in Russian].

3. Borisenko, V. (1980). Borotba demokratichnih sil za narodnu osvItu na UkraYinI v 60-90-h rokah HIH st. [The struggle of democratic forces for public education in Ukraine in the 60-90s of the XIX century.]. Kyiv: «Naukova dumka», 154 [in Ukrainian].

4. Kryzhanovska, O. (1997). Istoriia masonstva v Ukraini: Informatsino-dovidkovyi slovnyk. [History of Freemasonry in Ukraine: Information and reference dictionary.]. Kyiv, 126 [in Ukrainian].

5. Lavrovskiy, N. (1854). O drevne-russkih uchilischah. [About ancient Russian schools.]. Harkov, 198 [in Russian].

6. Pavlovskiy, I. (1906). K istorii Poltavskogo dvoryanstva 1802-1902 gg. [To the history of the Poltava nobility in 1802-1902]. Poltava, 3, 121 [in Russian]. 
7. Pavlovskiy, I. (1914). Poltavtsyi, ierarhi, gosudarstvennyie i obschestvennyie deyateli i blagotvoriteli. [Poltava residents, hierarchs, statesmen and public figures and benefactors]. Poltava, 279 [in Russian].

8. Prokopenko, L. (2008). Heneza ta rozvytok derzhavnoi osvitnoi polityky v Ukraini ( pochatok IX - XX st.): monohrafiia. [Genesis and development of state educational policy in Ukraine (IX - early XX century): monograph]. Donetsk: DRIDU NADU, 488 [in Ukrainian].

9. Samoilenko, H. (1996). Samoilenko O. H., Samoilenko S. H. Rozvytok osvity ta nauky v NIzhini v XVIII - XX st. [Development of science education in Nizhyn in the XVIII - XX centuries]. NIzhin, III, 25 [in Ukrainian].

10. Serhiienko, H. (1980). Dekabrysty i Shevchenko. [Decembrists and Shevchenko]. Kiev: Naukova dumka, 187 [in Ukrainian].

11. Stupak,. F. (1997). Diialnist blahodiinykh tovarystv Kyieva druhoi polovyny XIX - pochatku XX stolittia. [Activities of charitable societies of Kyiv in the second half of the XIX beginning of the XX century]. avtoref. dys...k. i. n.: 07.00.01. Kyivskyi natsionalnyi un-t im. T. H. Shevchenka. Kyiv, 23 [in Ukrainian].

12. Stuparyk, B. (1994). Z istorii stanovlennia himnaziinoi osvity. [3 історії становлення гімназійної освіти]. Ukrainskyi osvitnii zhurnal. Kyiv, 1, 56-67 [in Ukrainian].

\section{АНОТАЦЯ}

У статті досліджується проблема становлення та функціонування початкових навчальних закладів на Лівобережній Україні у 1805-1860 рр. Проаналізовано роль Міністерства освіти, яке залишило за собою контрольні функиіі, а утримання початкових навчальних закладів переклало на плечі громадськості.

Висвітлюється позиція консервативної частини суспільства, яка не підтримувала освітні ініціативи і позищію 
прогресивної частини громадськості, яка брала на себе левову частку фінансування у справі відкриття, функиіонування та розвитку повітових та приходських училищ на Лівобережній Украӥні у досліджуваний період.

Розкривається головна умова існування навчальних закладів, яка полягала у їх матеріальному забезпеченні. Авторка згадує імена меценатів, які активно впливали на розвиток освітнього процесу, жертвували на користь училищ, значні кощтти, книги, навчальні приладдя, меблі, медикаменти, помешкання тощуо.

Згадується роль національних меншин у становленні та функиіонуванні початкових навчальних закладів на Лівобережній Украӥні у досліджуваний період. Зокрема, висвітлюється ініціатива ніжинських греків, які переймалися освітніми проблемами своїх співвітчизників.

У статті висвітлюється роль почесних опікунів та наглядачів повітових училищ, які нерідко ставали $\ddot{x}$ постійними меченатами. Переймаючись господарськими проблемами, вони намагались покращити умови навчання своїх підопічних. Вказуються факти, які свідчать про їх безкорисливу благодійну справу, яка полягала у постійних пожертвуваннях.

Розглядається двостороннє фінансування початкових навчальних закладів, яке полягало у наданні матеріальної допомоги від почесних опікунів (наглядачів) навчальних закладів, а також приватних осіб.

Ключові слова: початкові навчальні заклади, повітові училищуа, почесний опікун, пожертвування, меценати, громадська ініціатива.

\section{АННОТАЦИЯ}

В статье исследуется проблема становления $u$ функиионирования начальных учебных заведений на Левобережной Украине в 1805-1860 г2. Проанализирована роль Министерства образования, которое оставило за собой 
контрольные функции, а содержание начальных учебных заведений перевело на плечи общественности.

Освещзается позиция консервативной части общества, которая не поддерживала образовательные инициативы и позицию прогрессивной части общественности, которая брала на себя львиную долю финансирования в деле открытия, функиионирования и развития уездных и приходских училищь на Левобережной Украине в исследуемый период.

Раскрывается главное условие существования учебных заведений, которое заключалось в их материальном обеспечении. Автор вспоминает имена меценатов, которые активно влияли на развитие образовательного процееса, жертвовали в пользу училищ значительные средства, книги, учебные пособия, мебель, медикаменты, ремонт и тому подобное.

Упоминается роль национальных меньшинств в становлении и функционировании начальных учебных заведений на Левобережной Украине в исследуемый период. В частности, освещуается инициатива нежинских греков, которые занимались образовательными проблемами своих соотечественников.

В статье освещуается роль почетных опекунов $и$ надзирателей уездных училищ, которые нередко становились их постоянными меценатами. Задаваясь хозяйственными проблемами, они пытались улучшить условия обучения своих подопечных. Указываются факты, свидетельствуюшие об их бескорыстном, благотворительном деле, которое заключалось в постоянных пожертвованиях.

Рассматривается двустороннее финансирование начальных учебных заведений, которое заключалось в предоставлении материальной помощуи от почетных опекунов (наблюдателей) учебных заведений, а также частных лиц.

Ключевые слова: начальные учебные заведения, уездные училищза, почетный опекун, пожертвования, меценаты, общественная иницииатива. 